\title{
Rekomendacje etyczne Polskiego Towarzystwa Historii Mówionej ${ }^{1}$
}

DOI: $10.26774 / \mathrm{wrhm} .285$ 


\section{Wprowadzenie}

Historia mówiona wymaga nie tylko wiedzy i umiejętności interpersonalnych, ale również dużej wrażliwości etycznej na każdym etapie pracy. Z tego powodu środowisko polskich oralistów sformułowało poniższe rekomendacje, widząc dużą potrzebę istnienia spisanych standardów postępowania w tej dziedzinie. Prezentowany zestaw rekomendacji stworzony został na podstawie wiedzy i doświadczenia członków Polskiego Towarzystwa Historii Mówionej, po uwzględnieniu podobnych tekstów stworzonych w innych krajach lub na potrzeby pokrewnych dziedzin nauki. Nie jest to instruktaż, jak robić wywiady ani też oficjalna wykładnia prawna. Niniejsze propozycje wyznaczają ogólne ramy postępowania oraz wskazują standardy i wartości, które należy mieć na względzie w historii mówionej. W konkretnych przypadkach należy kierować się zdrowym rozsądkiem i własnym sumieniem, a tam, gdzie jest to konieczne sięgnąć po profesjonalną poradę prawną. Przy mierzeniu się z sytuacjami skomplikowanymi lub nieoczywistymi rekomendujemy środowiskową superwizję, czyli rozmowę z innymi osobami profesjonalnie zajmującymi się historią mówioną.

\section{Dla kogo przeznaczone są Rekomendacje?}

Rekomendacje etyczne przeznaczone są dla wszystkich zajmujących się historią mówioną niezależnie od ich wykształcenia bądź zawodu: dla osób i instytucji nagrywających, posiadających, przechowujących oraz udostępniających nagrania historii mówionej, a także dla osób i instytucji, które korzystają z nich w swej działalności naukowej, edukacyjnej czy artystycznej.

\section{Treść rekomendacji}

1. Zamierzając nagrywać wywiady historii mówionej powinniśmy zawczasu zapoznać się z metodologią historii mówionej oraz jej specyfiką, aby mieć świadomość zarówno zalet, jak i ograniczeń tej metody.

2. Naszym obowiązkiem jest doskonalenie wiedzy i umiejętności oraz merytoryczne przygotowanie się przed każdą rozmową (wiedza historyczna na temat zagadnień, które mogą zostać poruszone).

3. Przygotowanie do rozmowy.

a. Powinniśmy uzgodnić miejsce i czas wywiadu, tak aby zapewnić osobie nagrywanej komfort i bezpieczeństwo, przy zachowaniu warunków pozwalających na rozmowę i nagranie;

1 Autorami rekomendacji są członkowie Polskiego Towarzystwa Historii Mówonej (Ртнм): Jakub Gałęziowski, Marcin Jarząbek, Joanna Urbanek i Karolina Żłobecka. 
b. przed nagraniem powinniśmy wyjaśnić potencjalnemu rozmówcy, w jakim celu chcemy z nim rozmawiać, jak będzie przebiegał wywiad, co stanie się z nagraniem, jak również kto będzie miał do niego dostęp. Jest to również czas wyjaśnienia ewentualnych wątpliwości, uzgodnienia ram wywiadu i możliwego czasu jego trwania oraz praw przysługujących rozmówcy (w tym odmowy odpowiedzi na zadane pytanie, prawa do rezygnacji z udziału w projekcie na każdym etapie, zastrzeżenia fragmentów wywiadu).

4. W trakcie rozmowy:

a. rozmówca powinien być traktowany z szacunkiem;

b. w miarę możliwości dokładamy starań, by stan psychiczny i sytuacja życiowa nagrywanego nie zostały pogorszone wskutek udzielonego wywiadu;

c. w trakcie nagrania zwracamy uwagę na kondycję rozmówcy, w razie potrzeby proponując mu przerwy lub zakończenie nagrania w danym dniu i umówienie kolejnego spotkania;

d. respektujemy godność osoby ludzkiej, podmiotowość i autonomię człowieka, jak również jego prawo do własnej historii życia, nawet jeśli pozostaje ona w sprzeczności z posiadaną przez nas wiedzą;

e. mamy prawo przerwać rozmowę, jeśli dobrostan psychiczny rozmówcy lub nasz nie pozwala na jej kontynuację. W pewnych przypadkach (jeżeli rozmowa przerwana została przez nas z powodów osobistych), zaleca się zaproponowanie osoby, która byłaby w stanie podjąć rejestrację rozmowy;

f. zadając pytania mamy na względzie wyrażaną na bieżąco wprost lub nie wprost wolę rozmówcy oraz jego emocje. Mamy jednak prawo dopytywać, jeśli jesteśmy przekonani, że uczyni to wywiad bogatszym i ciekawszym, a jednocześnie nie wyrządzi krzywdy nagrywanemu lub osobom trzecim; dopóki, dopóty rozmówca daje na to swoje przyzwolenie. Jeżeli je cofa, należy to respektować;

g. dokładamy starań, aby techniczna jakość nagrania była dobra.

5. Poufność. Zachowanie poufności w historii mówionej oznacza, że informacje osobiste o rozmówcy, niewynikające wprost z treści nagrania (w tym adres, stan zdrowia, posiadany majątek, treść rozmów poza nagraniem) nie zostaną przekazane innym osobom. Dane teleadresowe winny być dostępne jedynie w zakresie niezbędnym do opracowania i archiwizacji nagrania.

a. Jeżeli rozmówca nie życzy sobie występować pod własnym imieniem i nazwiskiem, można w nagraniu, przy jego archiwizacji lub udostępnianiu posłużyć się pseudonimem;

b. rozmówca może żądać poinformowania, jakie osoby będą miały dostęp do nagrania w czasie jego edycji, archiwizacji i na etapie udostępniania;

c. rozmówca może zastrzec fragmenty lub całość nagrania dla wybranych osób, może też żądać usunięcia fragmentu lub całości nagrania.

6. Wyrażenie zgody. 
a. Pod żadnym powodem nie wolno rejestrować rozmowy z drugim człowiekiem bez jego wiedzy i zgody;

b. do wyrażenia świadomej zgody służy tzw. „zgoda rozmówcy”, która - w zależności od potrzeb - może mieć formę pisemnej lub ustnej umowy. Umowa ustna powinna zostać nagrana, pisemna - podpisana w przynajmniej dwu kopiach (dla rozmówcy i dla osoby nagrywającej lub instytucji, dla której pracuje);

c. w treści zgody powinny zostać uwzględnione następujące elementy określające zasady i granice wykorzystania nagrania:

- zgoda osoby nagrywanej na nagranie i wykorzystanie wywiadu; informacja, dla jakich celów wywiad oraz dane osobowe, w nim zawarte, mogą zostać wykorzystane oraz przetworzone. Cele te należy wymienić: np. w pracy naukowej, na wystawach, w Internecie, w edukacji itp. Zgoda obejmuje tylko te sfery, które wprost zostaną wymienione; zamiast.

- imię i nazwisko osoby nagrywającej wywiad, jej dane kontaktowe oraz - jeśli dotyczy - nazwa i dane kontaktowe instytucji, dla której przeprowadzono rozmowę;

- informacja, że rozmówca zgadza się na archiwizację nagrania oraz w jakiej formie i w jakim miejscu (instytucji);

d. rozmówca ma prawo - po uzgodnieniu z nami - zastrzec dodatkowe kwestie, np. pseudonimizację, restrykcje dot. udostępniania nagrania (np. tylko za jego osobistą zgodą, tylko po jego śmierci itp.), obszary, w których jego relacja nie może być użyta itp., które zostaną uwzględnione w tekście „zgody rozmówcy”;

e. zgoda może mieć formę umowy pisemnej między nagrywającym (lub instytucją, dla której pracuje) a nagrywanym. W takim wypadku warto skorzystać z wzorów takich formularzy zgody proponowanych przez Ртнм lub kluczowe ośrodki historii mówionej w Polsce.

7. Archiwizacja.

a. Dobrym zwyczajem jest przekazywanie kopii nagrania rozmówcy;

b. powinniśmy zadbać o odpowiednie zabezpieczenie i przechowanie pozyskanych relacji audio lub wideo oraz dokumentacji i źródeł pozyskanych przy okazji wywiadu;

c. wywiady co do zasady archiwizowane są w wersji niezredagowanej. Powinna zostać wykonana co najmniej jedna kopia zapasowa nagrania.

8. Upublicznianie i udostępnienie nagrania.

a. Upublicznienia nagrania oznacza, że cała rozmowa lub jakaś jej część będzie dostępna dla każdego (np. w formie nagrania w Internecie, w publicznie dostępnym archiwum, w książce w postaci transkrypcji, na wystawie itp.). Udostępnienie oznacza, że rozmowa lub jej fragmenty będą dostępne - jednorazowo lub wielokrotnie - dla wybranego odbiorcy lub kręgu odbiorców;

b. decydując się na upublicznienie nagrania powinniśmy upewnić się: 
- czy mamy faktyczną lub dorozumianą zgodę od rozmówcy na taką formę upublicznienia?

- jaki jest cel tego upublicznienia i czy dla tego celu wybraliśmy najlepszą formę;

c. w zależności od zapisów w „zgodzie świadka” autoryzacja upublicznionej treści nagrania może być konieczna lub nie, jednakże dobrym zwyczajem jest przekazywanie informacji o zamierzonej publikacji lub upowszechnieniu nagrania oraz przekazywanie do autoryzacji powstałych na podstawie nagrania tekstów;

d. nie odpowiadamy za nieuprawnione wtórne użycie nagrań historii mówionej lub manipulację przez osoby trzecie, niemniej powinniśmy uwzględnić w swojej pracy takie ryzyko i starać się je zminimalizować;

e. w wypadku udostępniania nagrania historii mówionej przez instytucje (archiwa, muzea, instytucje kultury, instytucje edukacyjne itp.) powinny kierować się one czytelnymi procedurami. Zalecamy rejestrację zainteresowanych użytkowników w sposób analogiczny do systemu obowiązującego w archiwach państwowych lub publicznych bibliotekach;

f. osoby korzystające z nagrań, decydując się na udostępnienie lub upublicznienie treści relacji, powinny mieć na względzie dobro nagrywanej osoby, jej bliskich oraz osób, których dane pojawiają się w nagraniu. W uzasadnionych przypadkach należy powstrzymać się od udostępniania lub upublicznienia nagrania, nawet jeśli rozmówca wyraził na to swoją formalną zgodę.

9. Prawa autorskie i ochrona danych osobowych.

a. Przestrzegamy obowiązujących w Polsce przepisów z zakresu ochrony danych osobowych oraz praw autorskich;

b. zakładamy, że w myśl polskiego prawa autorskiego nagranie wywiadu historii mówionej jest utworem, a jego twórcami są - jeśli nie umówili się inaczej - w równych proporcjach wszyscy, którzy wnieśli doń swój twórczy wkład. W praktyce oznacza to rozmówcę i osobę przeprowadzającą wywiad oraz - jeśli byli obecni - kamerzystę i dźwiękowca. Wszyscy oni powinni zostać uwzględniani w opisie nagrania. Rozmówca z reguły rezygnuje ze swoich majątkowych praw autorskich zgadzając się na nieodpłatne użycie nagrania we wskazanych „polach eksploatacji" (naukowych, edukacyjnych, w Internecie, literaturze itp.);

c. nie wolno wykorzystywać zawartych w treści relacji danych osobowych nagrywanego lub osób trzecich dla celów innych niż ustalone w treści zgody na nagranie.

Tekst przyjęty przez Walne Zgromadzenie Pтнм w Lublinie 13 maja $2018 r$. 


\section{Ethical guidelines of the Polish Oral History Association ${ }^{2}$ (translation)}

\section{Introduction}

Oral history requires not only knowledge and interpersonal skills, but also a high degree of ethical sensitivity at every stage of work. For this reason, the community of Polish oral historians has formulated the following guidelines, seeing the great need for written standards of conduct in this field. The presented set of guidelines is based on the knowledge and experience of members of the Polish Oral History Association, taking into account similar texts written in other countries or for the needs of related fields of study. This is not a set of instructions on how to conduct interviews or an official legal interpretation. These proposals set out a general framework for conduct and indicate the standards and values to be considered in oral history. In specific cases, you should use common sense and your own conscience, and where necessary, seek professional legal advice. When dealing with complicated or non-obvious situations, we recommend community supervision; i.e., talking to other people who are professionally involved in oral history.

\section{Who are the Guidelines for?}

These ethical guidelines are intended for all those involved in oral history, regardless of their education or profession: for people and institutions recording, owning, storing, and sharing oral history recordings, as well as for people and institutions that use such materials in their scholarly, educational, or artistic activities.

\section{Text of the guidelines}

1. When we plan to record oral history interviews, we should familiarize ourselves with the oral history methodology and its specifics in order to be aware of both the advantages and limitations of this method.

2. It is our duty to improve our knowledge and skills as well as substantive preparation before each interview (historical knowledge on the issues that may be raised).

3. Preparation for the interview:

2 The Authors of the recommendations are members of Polish Oral History Association (ронА): Jakub Gałęziowski, Marcin Jarząbek, Joanna Urbanek and Karolina Żłobecka. 
a. We should arrange the place and time of the interview so as to ensure the comfort and safety of the person being recorded, while maintaining conditions allowing for the interview and recording;

b. Before the recording, we should explain to the potential interlocutor for what purpose we want to talk to him / her, how the interview will proceed, what will happen with the recording, and who will have access to it. This is also the time to clarify any issues, agreeing on the framework of the interview and its possible duration as well as the rights of the interlocutor (including refusal to answer any question that is asked, the right to resign from participation in the project at any stage, reservation of excerpts from the interview).

4. During the conversation:

a. The interlocutor should be treated with respect;

b. As far as possible, we make every effort to ensure that the mental state and life situation of the recorded person are not worsened as a result of the interview;

c. During the recording, we pay attention to the condition of the interlocutor, if necessary, suggesting breaks or ending the recording on a given day and arranging another meeting;

d. We respect the dignity of the human being, human subjectivity and autonomy, as well as his / her right to his / her own life history, even if it is in conflict with our knowledge;

e. We have the right to stop the conversation if the psychological well-being of the interlocutor or ours does not allow for its continuation. In some cases (if the conversation was interrupted by us for personal reasons), it is recommended to propose a person who would be able to record the conversation;

f. When asking questions, we take into account the wishes of the interlocutor, expressed directly or indirectly, and his / her emotions. However, we have the right to ask questions if we are convinced that they will make the interview richer and more interesting, and at the same time will not harm the recorder or third parties, as long as the interlocutor gives his / her consent to this. If he / she withdraws consent, this must be respected;

g. We make every effort to ensure that the technical quality of the recording is good.

5. Confidentiality. Maintaining confidentiality in oral history means that personal information about the interlocutor, not resulting directly from the content of the recording (including address, health condition, possessions, and the content of conversations outside the recording) will not be disclosed to other people. Contact details should be available only to the extent necessary for the processing and archiving of the recording.

a. If the interlocutor does not wish to appear under his / her own name and surname, a pseudonym may be used in the recording, when archiving it or making it available; 
b. The interlocutor may request information which persons will have access to the recording during its editing, archiving and sharing;

c. The interlocutor may reserve parts of or the whole of the recording for selected people, and may also demand that a part of or the whole of the recording be deleted.

6. Consent.

a. Under no circumstances should you record a conversation with another person without their knowledge and consent;

b. To express informed consent, so-called "Interlocutor's Consent" is required, which, depending on the needs, may be in the form of a written or oral agreement. The oral contract should be recorded, written and signed in at least two copies (for the interlocutor and for the person recording or the institution for which he / she works);

c. The content of the consent should include the following elements specifying the rules and limits of using the recording:

- the consent of the person being recorded to the recording and use of the interview; information for what purposes the interview and the personal data contained therein may be used and processed. These goals should be mentioned: e.g., in academic work, at exhibitions, on the Internet, in education, etc. - consent covers only those spheres that are explicitly mentioned;

- the name and surname of the interviewer, their contact details, and, if applicable, the name and contact details of the institution for which the interview was conducted;

- information that the interlocutor agrees to the archiving of the recording and in what form and in what place (institution);

d. The interlocutor has the right, after agreeing with us, to stipulate additional issues, e.g., pseudonymisation, restrictions on sharing the recording (e.g. only with his personal consent, only after his / her death, etc.), areas where his / her relationship cannot be used, etc., which will be included in the text for "interlocutor's consent;"

e. Consent may be in the form of a written agreement between the recorder (or the institution he / she works for) and the recorded. In this case, it is worth using the templates of such consent forms proposed by PTHM or key oral history centres in Poland.

7. Archiving.

a. It is a good practice to give a copy of the recording to your interlocutor;

b. We should ensure appropriate protection and storage of the acquired audio or video reports, documentation, and sources obtained during the interview;

c. As a rule, the interviews are archived in an unedited version. At least one backup of the recording should be made.

8. Publication and sharing of the recording.

a. Making the recording public means that the entire conversation or some part of it will be available to everyone (e.g., in the form of a recording on the Internet, 
in a publicly accessible archive, in a book in the form of a transcript, at an exhibition, etc.). Sharing means that the conversation or its fragments will be available - once or repeatedly - to a selected recipient or group of recipients;

b. When deciding to publish a recording, we should make sure:

- We have actual or implied consent from the interlocutor for this form of publication,

- What the purpose of this publication is and that we have chosen the best form for this purpose;

c. Depending on the provisions in the "interlocutor's consent," authorization of the published content of the recording may or may not be necessary; however, it is good practice to provide information about the intended publication or dissemination of the recording and to submit for authorization the texts created on the basis of the recording;

d. We are not responsible for the unauthorized re-use of oral history recordings or manipulation by third parties; however, we should consider such risks in our work and try to minimize them;

e. Institutions (archives, museums, cultural institutions, educational institutions, etc.) should follow clear procedures when sharing recorded oral history. We recommend registering interested users in a manner analogous to the system in force in state archives or public libraries;

f. When deciding to share or make public the content of the report, people using the recordings should take into account the well-being of the person being recorded, their relatives and people whose data appear in the recording. In justified cases, one should refrain from sharing or publishing the recording, even if the interlocutor has given his / her formal consent for this.

9. Copyright and personal data protection.

a. We comply with the provisions in force in Poland on the protection of personal data and copyright;

b. We assume that, according to Polish copyright law, the recording of an oral history interview is a work, and its authors are - unless agreed otherwise - in equal proportions all those who have contributed to it. In practice, this means the interlocutor and interviewer and, if present, the cameraman and sound technician. All of these persons should be included in the description of the recording. The interlocutor usually resigns from his economic copyright, agreeing to use of the recording free of charge in the indicated "fields of exploitation" (scholarly, educational, Internet, literature, etc.);

c. It is not permissible to use the personal data of the recorded or third parties contained in the content of the report for purposes other than those specified in the consent to the recording. 